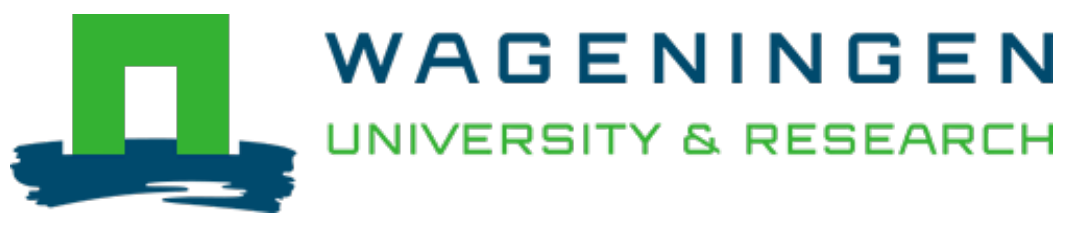

\title{
The politics of co-production: participation, power, and transformation
}

Current Opinion in Environmental Sustainability

Turnhout, E.; Metze, T.A.P.; Wyborn, Carina; Klenk, Nicole; Louder, Elena

https://doi.org/10.1016/j.cosust.2019.11.009

This article is made publicly available in the institutional repository of Wageningen University and Research, under the terms of article $25 \mathrm{fa}$ of the Dutch Copyright Act, also known as the Amendment Taverne. This has been done with explicit consent by the author.

Article $25 \mathrm{fa}$ states that the author of a short scientific work funded either wholly or partially by Dutch public funds is entitled to make that work publicly available for no consideration following a reasonable period of time after the work was first published, provided that clear reference is made to the source of the first publication of the work.

This publication is distributed under The Association of Universities in the Netherlands (VSNU) 'Article $25 \mathrm{fa}$ implementation' project. In this project research outputs of researchers employed by Dutch Universities that comply with the legal requirements of Article $25 \mathrm{fa}$ of the Dutch Copyright Act are distributed online and free of cost or other barriers in institutional repositories. Research outputs are distributed six months after their first online publication in the original published version and with proper attribution to the source of the original publication.

You are permitted to download and use the publication for personal purposes. All rights remain with the author(s) and / or copyright owner(s) of this work. Any use of the publication or parts of it other than authorised under article $25 \mathrm{fa}$ of the Dutch Copyright act is prohibited. Wageningen University \& Research and the author(s) of this publication shall not be held responsible or liable for any damages resulting from your (re)use of this publication.

For questions regarding the public availability of this article please contact openscience.library@wur.nl 


\section{The politics of co-production: participation, power, and transformation \\ Esther Turnhout ${ }^{1}$, Tamara Metze ${ }^{2}$, Carina Wyborn ${ }^{3,4}$, Nicole Klenk ${ }^{5}$ and Elena Louder ${ }^{6}$}

\begin{abstract}
Literature on co-production is booming. Yet, most literature is aspirational and methodological in nature, focusing on why coproduction is important for environmental governance and knowledge production and how it should be done, and does not address the question why these processes often fail to achieve stated objectives of empowerment and societal transformation. In this review, we address this gap by reviewing literature on the political and power dimensions of co-production. Our review shows how depoliticization dynamics in co-production reinforce rather than mitigate existing unequal power relations and how they prevent wider societal transformation from taking place. Drawing on literature about participation, deliberative governance, and democracy, the review concludes by emphasizing the importance of (re)politicizing co-production by allowing for pluralism and for the contestation of knowledge.
\end{abstract}

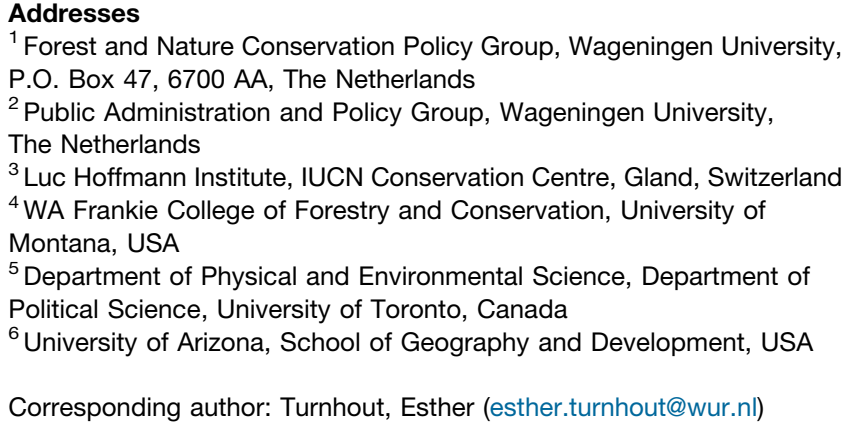

${ }^{5}$ Department of Physical and Environmental Science, Department of Political Science, University of Toronto, Canada

${ }^{6}$ University of Arizona, School of Geography and Development, USA

Corresponding author: Turnhout, Esther (esther.turnhout@wur.nl)

\section{Current Opinion in Environmental Sustainability 2019, 42:15-21}

This review comes from a themed issue on Advancing the science of actionable knowledge for sustainability

Edited by James C Arnott, Katharine J Mach and Gabrielle WongParodi

Received: 10 June 2019; Accepted: 23 November 2019

https://doi.org/10.1016/j.cosust.2019.11.009

1877-3435/@ 2019 Published by Elsevier B.V.

\section{Introduction}

In the last few decades, we have seen a participatory trend in environmental governance as well as in knowledge production [1-6], resulting in new relationships between governments, industries, civil society, and science [7-9]. Under a variety of concepts and labels including coproduction, transdisciplinarity, science-policy interface, democratization of expertise, and knowledge brokering, numerous projects and interventions have been set up to facilitate participatory and collaborative processes that aim to integrate different ways of knowing and jointly develop knowledge that is actionable and that contributes to effective and legitimate solutions and the transformation of society [10]. ${ }^{1}$ In many cases however, these projects and interventions do not live up to their stated objectives $[11,12]$. We know from literature about participation that the outcomes of participatory interventions can even be paradoxical, reinforcing the problems that they intended to solve [4] but now sanctioned or legitimized by the participatory process; this is why participation has been referred to as tyrannical [13].

Despite this, much of the literature on co-production is aspirational - explaining the merits and importance of co-production - or methodological - providing guidelines for facilitation and communication to improve the execution of co-production projects. This literature presents best practices and lessons learnt, and offers checklists of factors and conditions for success [14-16]. While these checklists can be useful, the problem of this literature is that it does not offer a meaningful explanation of how and why these processes fail [17]. An important reason for this lack of understanding of failure is that the co-production literature has not paid sufficient attention to the role of power and politics in shaping processes and outcomes. This omission is surprising since literature on participatory and deliberative governance has historically addressed these two factors as crucial [13,18-20].

In this article, we discuss how literature ${ }^{2}$ has addressed the political and power dimensions of co-production

\footnotetext{
${ }^{1}$ In this article we use the term co-production as a shorthand for participatory modes of knowledge production. We do not refer to the analytical concept of co-production as defined by Jasanoff (2004, States of Knowledge, Routledge), which suggests that "the ways in which we know and represent the world (both nature and society) are inseparable from the ways in which we chose to live in it".

${ }^{2}$ In our discussion, we focused on studies of community-based and local processes and to lesser extent on those science driven initiatives which often use the label citizen science. We do feel however, that our findings are also relevant for that community of scholars and practitioners (also see Pettibone, L. et al. Transdisciplinary sustainability research and citizen science: Options for mutual learning. GAIA 27, 222-225 (2018).
} 
(or not) and how these dimensions have affected the outcomes of co-production. By complementing this discussion with findings from participation, deliberative governance and democracy literature, we contribute to a better understanding of how and why co-production can fail and how this can be prevented.

\section{Unequal power relations}

A key premise of co-production is that to address complex problems, scientific expertise alone is not sufficient and that the contribution of stakeholders' knowledge is vital to create knowledge that is not only of scientific high quality but also socially robust [21-24]. Underpinning these efforts is an ethic of mutuality, reciprocity, and equality between scientific and other experts, including practitioners, as well as citizens and civil society groups. Yet, this equality among participants is not self-evident. Literature on participation has demonstrated that elite actors, for example from government, large NGOs, or scientists, have more time and resources available, often initiate these processes, define the scope for participation, have more knowledge and skills, and are, for all these reasons that resonate with social-cultural biases, better able to articulate a contribution that is considered relevant and important $[4,21,25]$. Consequently, elite actors are able to shape these processes to serve their interests [26,27]. In a co-production context, these power inequalities are further compounded by the strong authority that is attributed to scientific expertise vis-a-vis other knowledge systems [28,29].

These uneven power relations are often present from the start; for example when individual citizens or representatives from community organizations or non-profits are invited to participate into processes of which the scope for participation and the problem framing of a project have already been defined by a narrower set of elite actors [30]. This is further exacerbated by the fact that these elite actors are often paid to participate as part of their professional roles, while the other participants are expected to volunteer their time [31]. Groups who already have established relationships across science, policy and community actors are also more often invited to participate than unorganized citizens or less well-known groups [31].

These inequalities become even more pronounced when co-production involves collaboration between Western and Global South stake-holders and knowledge-holders. This inherent Western bias has been problematized. Specifically, North-South politics, the ongoing challenges of colonialism, the contexts characterized by conflict, and communities that are not able to self-organize nor given support by local decision-makers, make the current guiding logics and principles of co-production problematic [32-35]. Notions of trust, willingness to collaborate, momentum, and symmetrical power relations cannot be taken for granted and failing to recognize this could have detrimental consequences [36]. For example, a study of land reform processes in Ghana found that co-production became a conduit for private wealth accumulation within the broader context of weak institutional capacities and poor governance [37]. In such a context, those with power and resources were able to take advantage of the co-production process and undermine the efforts to promote more equitable governance [37].

These biases towards elite actors are worrying because they result in these processes reproducing or even exacerbating existing inequalities. And this also affects the quality, usefulness, and legitimacy of their outcomes because they are less likely to result in solutions that resonate with and are usable for non-elite groups [35,38-40].

\section{Depoliticization}

Depoliticization is a key factor in the reproduction (and justification) of the unequal power relations discussed in the previous section. What we have seen in co-production, and in participatory processes more generally, is that they are often dominated by a particular depoliticized discourse that uses rational and scientific arguments to evoke universalized ideas of what is 'the best' solution. This discourse ignores political differences between participants, including positions, interests and beliefs, and pressurizes non-elite participants to stay within this scientifically sanctioned rationality. For example: they are expected to act in accordance with pre-set ideas of what it means to be reasonable; to allow their knowledge to be integrated into science-based frameworks; to compromise to enable the resolution of conflict in all its forms; or to subscribe to a consensus view [41-45].

These problems have been well documented in literature that focusses on the politics and democratic quality of participatory processes, and these scholars argue that there are no simple solutions $[4,13]$. For these reasons, it is surprising to see that many co-production studies are silent on this issue. A typical example of this is a coastal research project on social and ecological changes associated with development of liquid natural gas (LNG) extraction in Australia [46]. By ignoring the economic and political power of the LNG industry, authors neglect an important possible explanation of failure to change the situation [46]. If addressed at all, much of the coproduction literature offers recommendations to ensure good processes, for example about importance of trust and open communication $[47,48]$, which fail to address power and politics of these complex issues, including a neglect of how the results will feed into formal politized decisionmaking structures. Other literature emphasizes the importance of making the 'right' connections between researchers, decision-makers and representatives of stakeholder groups, to ensure inclusivity and representativeness, and the need to develop a vocabulary and skills for bridging diverse boundaries [49-53]. This focus on 
new connections, language and skills often does not reflect on the socio-cultural biases in the co-production process, and the potential harm (for example the loss of particular political interests, norms and values in the co-production process) that can result from attempts to realise these values and conditions. Without this critical reflection, these proposals are at best incomplete and at worst harmful.

As we have shown so far, by failing to address the political and power dimensions of co-production, these processes in practice end up reinforcing and strengthening traditional modes of knowledge production and dissemination, in which scientists are cast as holders of knowledge and other stakeholders as holders of values or perspectives to be corrected by science, as receivers of scientific expertise, and as cocreators of solutions $[5,9,54,55]$.

\section{Empowerment}

Some studies do recognize the importance of managing power dynamics within co-production processes. They mostly call for practical measures, such as more attention to sources of funding, project motivation, and loci of power [56] and they warn that co-production may empower some actors over others and encourage awareness of this $[11,21,29,32,57]$. Other authors allude to the fact that decision-makers involved in co-production will be subject to political and social pressures [58] and suggest that it is important to create 'horizontal' rather than 'hierarchical' relationships between actors [59,60]. Part of the co-production literature takes this a step further and considers the empowerment of marginal actors as a fundamental goal of such projects [61] and argues that co-production requires deepening engagement with inequality and exclusion as well as a direct confrontation with current power asymmetries [62]. This explicit focus on empowerment and the politics therein tend to be less present within studies of co-production that are driven by a rationale that sees co-production as a means through which scientific knowledge is mobilised to 'solve' scientific problems. These studies in particular risk failing to address the key issue of representation; who participates and what values, perspectives and interests do these participants represent, and deliberation; how can all voices be voiced and included in a legitimate way.

Addressing the power dimensions of participatory processes is a long-standing concern in scholarship on deliberative governance and democracy. This literature emphasizes the importance of making power explicit and of reflecting on the, often implicit, assumptions and expectations held by participations about each other's roles and responsibilities [63]. In this perspective, power is unavoidable and should be discussed openly. The central idea is to shift the debate from one shaped by 'power-over' - where some participants are dominated or manipulated by others - to 'power-with' — where all stakeholders are empowered to generate something new and connect with something larger than themselves $[19,64]$. This will inevitably entail a degree of disempowerment of science and other elites, as has been advocated in calls for humility on the part of science [65-67]. Cases of co-production describe how the ability of elites to step back was central to allowing the renegotiation of roles and responsibilities of participants and the redefinition of the objectives and priorities of the project to reflect those of the community and empower traditional marginalized voices within decision-making $[30,68,69]$.

In this view, conflicts are unavoidable and it is paramount to resist their premature closure. Drawing on agonistic democratic theory [70,71] amongst others, literature has critiqued the imperatives of integration and consensus as guiding logics of co-production and has highlighted the creative and productive potential importance of contestation, pluralism, informed dissent, and difference $[38,40,41,43,72-78,67]$. One study details an example of co-producing knowledge full of conflict, tensions and risks in an informal settlement in South Africa, which bore local fruit and had positive spill over governance effects without beginning by crafting a shared vision of the future [35]. Similarly, the Loweswater Care project was able to create equal relationships between different forms of scientific and local knowledge and develop and test management interventions to address local pollution by encouraging the mutual criticism and contestation of all knowledge claims $[79,80]$.

\section{Societal transformation}

There is the expectation that co-production results in actionable knowledge that can catalyse broader societal transformation of governance and knowledge production processes $[3,17,81]$. The question is if this expectation is being met. The bulk of the literature does not address change outside the boundaries of the specific co-production projects or processes which are often inherently small scale and inclusive of a limited number of individuals [31,59,82-84]. Some articles do point to the wider impact of learning taking place within co-production processes but do not discuss this in depth [85]. Hence, this project focus has limitations [12]. We have found cases where attempts to innovate science-policy relations towards co-production were thwarted because the existing political context favoured a traditional role of science [86,87]. To prevent this, co-production processes can be organized as part of a broader political agenda [88]. One example discusses how technical water committees in the city of Caracas were able to empower poor citizens because they were seen to be part of a broader political project to change power relations between the state and the citizen and to promote a new form of citizenship [89].

This issue of the limited scope of co-production processes, and of the articles documenting these 
processes, is symptomatic of a wider trend to organize governance, societal change, and transformation processes in projects (or niche innovations) [90] which are required to demonstrate their effectiveness [91]. Projects have clear advantages because they are bounded and have clearly defined goals which allow for such evaluation of effectiveness to take place. The small scale of projects also has the advantage that they can be seen as testing-grounds to try out new ideas [92]. However, the flipside of this is also immediately clear: the interests and actors outside project boundaries are not addressed and there are no mechanisms in place to contribute to their transformation [12,93]. Thus, by not engaging with, nor challenging the power structures inherent to the wider context, the organization of co-production in the form of projects can be seen as another form of depoliticization.

This poses a dilemma for the practice of co-production: the disconnect between co-production projects and outside actors and interests is both a strength and a weakness. When pitfalls related to depoliticization and empowerment can be avoided, there are clear benefits to co-production projects. They are manageable to organize and to get funded, and they can provide contained spaces for experimentation in which it is safe to fail. In difficult, or even hostile, political contexts, this can also be the best available option to catalyse societal transformation [35]. At the same time this containment also prevents societal transformation because actors and interests outside project boundaries are not included or transformed [12,92].

\section{Conclusion}

In this literature review, we have shown that co-production processes can end up reproducing, rather than mitigating, existing unequal power relations and that they often do not contribute to societal transformation. At the basis of these failures lies a strong tendency to depoliticize co-production. We have discussed three ways in which this depoliticization can be recognized. First, many co-production projects are led by a rationale of science-driven impacts and do not challenge existing hierarchies between scientific and other knowledge holders, which then means that they themselves serve to reinforce existing structures of power that privilege scientific knowledge over other ways of knowing. Second, depoliticization can be recognized in the tendency of co-production projects to strive for consensus and for solutions that are considered rational according to elite perspectives, but which may cover up fundamental differences among participants in terms of stakes, power, access to resources, vulnerability, and risk. Third, it occurs when co-production stays confined to project boundaries without engaging the wider political context in which these projects are embedded. While this orientation of co-production to the processes within projects has clear benefits, it also prevents co-production from contributing to societal transformation, or even hinders this transformation by replicating existing power differences. We see the same depoliticization tendencies in research on participation and knowledge production and use [94], and while strategies to address within-project power dynamics are clearly valuable, if they are put forward in isolation of those that challenge existing societal structures, we fear their impacts will be limited.

Recognizing the politics of co-production both in practices and in research will require a rethinking and a repoliticization of these processes that goes beyond simplistic checklists of do's and don'ts. We suggest that it is important to understand co-production as both a knowledge-making and a political practice which is inevitably imbued with unequal power relations that need to be acknowledged but cannot be managed away. Instead, it will be vital to allow for pluralism, create scope to highlight differences and, enable the contestation of interests, views, and knowledge claims. In addition, we need to better understand the mechanisms that do accomplish successful empowerment in co-production projects in isolated projects and the ways that those mechanisms can be connected to, or embedded within, broader processes of societal transformations. We recognize that such a (re)politicization of co-production can be risky and it may not result in actionable knowledge in a depoliticized or instrumental sense, but nevertheless argue that it is essential for co-production to realize its transformative potential.

\section{Conflict of interest}

Hereby I declare that the authors have no conflict of interest.

\section{Acknowledgements}

This work was supported by the National Socio-Environmental Synthesis Center (SESYNC) under funding received from the National Science FoundationDBI-1639145. Any opinions, findings, and conclusions or recommendations expressed in this material are those of the author(s) and do not necessarily reflect the views of the National Science Foundation.

\section{References}

1. Chilvers $\mathrm{J}$, Kearnes M: Remaking participation in science and democracy. Sci Technol Hum Values 2019 http://dx.doi.org/ 10.1177/0162243919850885.

2. Lemos MC, Arnott JC, Ardoin NM, Baja K, Bednarek AT, Dewulf A, Fieseler C, Goodrich KA, Jagannathan K, Klenk N et al:: To coproduce or not to co-produce. Nat Sustain 2018, 1:722-724 http://dx.doi.org/10.1038/s41893-018-0191-0.

3. Miller CA, Wyborn C: Co-production in global sustainability: histories and theories. Environ Sci Policy 2018:241-251 http://dx doi.org/10.1016/j.envsci.2018.01.016.

4. Turnhout E, Van Bommel S, Aarts N: How participation creates citizens: participatory governance as performative practice. Ecol Soc 2010, 15(4):26 http://dx.doi.org/10.5751/ES-03701150426.

5. Turnhout E, Stuiver M, Judith J, Harms B, Leeuwis C: New roles of science in society: different repertoires of knowledge brokering. Sci Public Policy 2013, 40(3):354-365 http://dx.doi. org/10.1093/scipol/scs114. 
6. Fransman $\mathrm{J}$ : Charting a course to an emerging field of "research engagement studies": a conceptual metasynthesis. Res All 2018, 2(2):185-229 http://dx.doi.org/10.18546/ rfa.02.2.02.

7. Fischer F: Citizens, Experts, and the Environment: The Politics of Local Knowledge. Duke University Press; 2000.

8. Hajer MA: Authoritative Governance: Policy Making in the Age of Mediatization. Oxford University Press; 2009.

9. Metze TAP: Discursive power in deliberations: a case of redevelopment for the creative economy in the Netherlands. Policy Soc 2009, 28 http://dx.doi.org/10.1016/j. polsoc.2009.08.006.

10. Mach KJ, Lemos MC, Meadow AM, Wyborn C, Klenk N, Arnott JC, Ardoin NM, Fieseler C, Moss RH, Nichols L et al: Actionable knowledge and the art of engagement. Curr Opin Environ Sustain 2019. Forthcoming

11. Oliver K, Kothari A, Mays N: The dark side of coproduction: do the costs outweigh the benefits for health research? Health Res Policy Syst 2019, 17:33 http://dx.doi.org/10.1186/s12961019-0432-3.

12. Felt U, Igelsböck J, Schikowitz A, Völker T: Transdisciplinary sustainability research in practice: between imaginaries of collective experimentation and entrenched academic value orders. Sci Technol Hum Values 2016, 41(4):732-761 http://dx. doi.org/10.1177/0162243915626989.

13. Cooke B, Kothari U: The case for participation as tyranny. In Participation, the New Tyranny? Edited by Cooke B, Kothari U. Zed Books; 2001.

14. Pohl C, Krütli P, Stauffacher M: Ten Reflective Steps for Rendering Research Societally Relevant. GAIA; 2017 http://dx.doi.org/ 10.14512/gaia.26.1.10.

15. Beier P, Hansen LJ, Helbrecht L, Behar D: A how-to guide for coproduction of actionable science. Conserv Lett 2017, 10 (3):288-296 http://dx.doi.org/10.1111/conl.12300.

16. Reed MS, Stringer LC, Fazey I, Evely AC, Kruijsen JHJ: Five principles for the practice of knowledge exchange in environmental management. J Environ Manage $2014 \mathrm{http}: / / \mathrm{dx}$. doi.org/10.1016/j.jenvman.2014.07.021.

17. Wyborn C, Datta A, Leith P, Miller C, Van Kerkhoff L, Chaffin B, Montana J, Ryan M: Co-producing sustainability: reordering the relationships between science, policy, and practice. Annu Rev Environ Resour 2019, 44:319-346.

18. Becker M, Dryzek John S: Deliberative democracy and beyond. liberals, critics, contestations. Polit Vierteljahresschr 2007, 43 (3):524-526 http://dx.doi.org/10.1007/s11615-002-0062-0.

19. Hendriks CM: Deliberative governance in the context of power Policy Soc 2009, 28(3):173-184 http://dx.doi.org/10.1016/j. polsoc.2009.08.004

20. Warren ME: Deliberative democracy and authority. Am Polit Sci Rev 1996, 90(1):46-60 http://dx.doi.org/10.2307/2082797.

21. Clark WC, van Kerkhoff L, Lebel L, Gallopin G: Crafting Usable Knowledge for Sustainable Development 2016, 113 17, 4570-4578.

22. Mauser W, Klepper G, Rice M, Schmalzbauer BS, Hackmann H, Leemans $\mathrm{R}$, Moore $\mathrm{H}$ : Transdisciplinary global change research: the co-creation of knowledge for sustainability. Curr Opin Environ Sustain 2013, 5:420-431.

23. Pellizzoni $L$ : The myth of the best argument: power, deliberation and reason. Br J Sociol 2001, 52(1):59-86 http://dx. doi.org/10.1080/00071310020023037.

24. Gibbons M: Science's new social contract with society. Nature 1999, 402:81-84.

25. Cornwall A: Making Spaces, Changing Places: Situating Participation in Development. Institute of development studies; 2002.

26. Parkinson J: Deliberating in the Real World: Problems of Legitimacy in Deliberative Democracy. Oxford University Press; 2006.
27. Parkinson J: Democratising deliberative systems. In Deliberative Systems: Deliberative Democracy at the Large Scale. Edited by Parkinson J, Mansbridge J. Cambridge University Press; 2012:151-172.

28. Nadasdy P: Reevaluating the co-management success story. Arctic 2003, 56:367-380.

29. Goldman MJ, Turner MD, Daly M: A critical political ecology of human dimensions of climate change: epistemology, ontology, and ethics. Wiley Interdiscip Rev Clim Change 2018, 9 (4):e526 http://dx.doi.org/10.1002/wcc.526.

30. Dalgarno $\mathrm{M}$, Oates $\mathrm{J}$ : The meaning of co-production for clinicians: an exploratory case study of practitioner trainers in one recovery college. J Psychiatr Ment Health Nurs 2018, 25(56):349-357 http://dx.doi.org/10.1111/jpm.12469.

31. Frantzeskaki N, Rok A: Co-producing urban sustainability transitions knowledge with community, policy and science. Environ Innov Soc Transitions 2018, 29:47-51 http://dx.doi.org/ 10.1016/j.eist.2018.08.001.

32. Chilisa B: Decolonising transdisciplinary research approaches: an African perspective for enhancing knowledge integration in sustainability science. Sustain Sci 2017, 12 (5):813-827 http://dx.doi.org/10.1007/s11625-017-0461-1.

33. Meehan K, Klenk NL, Mendez F: The geopolitics of climate knowledge mobilization. Sci Technol Hum Values 2018, 43 (5):759-784 http://dx.doi.org/10.1177/0162243917745601.

34. Schmidt L, Pröpper M: Transdisciplinarity as a real-world challenge: a case study on a North-South collaboration. Sustain Sci 2017, 12:1-15 http://dx.doi.org/10.1007/s11625-0170430-8.

35. van Breda J, Swilling M: The guiding logics and principles for designing emergent transdisciplinary research processes: learning experiences and reflections from a transdisciplinary urban case study in Enkanini informal settlement, South Africa. Sustain Sci 2019, 14(3):823-841 http://dx.doi.org/10.1007/ s11625-018-0606-X.

36. Foley RW, Wiek A, Kay B, Rushforth R: Ideal and reality of multistakeholder collaboration on sustainability problems: a case study on a large-scale industrial contamination in Phoenix, Arizona. Sustain Sci 2017, 12(1):123-136 http://dx.doi.org/ 10.1007/s11625-016-0393-1.

37. Akaateba MA, Huang $\mathrm{H}$, Adumpo EA: Between co-production and institutional hybridity in land delivery: insights from local planning practice in peri-urban Tamale, Ghana. Land Use Policy 2018, 72:215-226 http://dx.doi.org/10.1016/j. landusepol.2017.12.043.

38. Asayama S, Sugiyama M, Ishii A, Kosugi T: Beyond solutionist science for the Anthropocene: to navigate the contentious atmosphere of solar geoengineering. Anthr Rev 2019, 6(1-2):1937 http://dx.doi.org/10.1177/2053019619843678.

39. Schmidt L, Neuburger M: Trapped between privileges and precariousness: tracing transdisciplinary research in a postcolonial setting. Futures 2017, 93:54-67 http://dx.doi.org/ 10.1016/j.futures.2017.07.005.

40. Denney JM, Case PM, Metzger A, Ivanova M, Asfaw A: Power in participatory processes: reflections from multi-stakeholder workshops in the Horn of Africa. Sustain Sci 2018, 13(3):879-893 http://dx.doi.org/10.1007/s11625-018-0533-x.

41. Klenk N, Meehan K: Climate change and transdisciplinary science: problematizing the integration imperative. Environ $\mathrm{Sci}$ Policy 2015, 54(December):160-167 http://dx.doi.org/10.1016/j. envsci.2015.05.017.

42. Siebenhüner B: Conflicts in transdisciplinary research: reviewing literature and analysing a case of climate adaptation in Northwestern Germany. Ecol Econ 2018, 154 (December):117-127 http://dx.doi.org/10.1016/j. ecolecon.2018.07.011.

43. Andersson $\mathrm{J}$, Westholm E: Closing the future: environmental research and the management of conflicting future value orders. Sci Technol Hum Values 2019, 44(2):237-262 http://dx. doi.org/10.1177/0162243918791263. 
44. Bréthaut C, Gallagher L, Dalton J, Allouche J: Power dynamics and integration in the water-energy-food nexus: learning lessons for transdisciplinary research in Cambodia. Environ Sci Policy 2019, 94(April):153-162 http://dx.doi.org/10.1016/j. envsci.2019.01.010.

45. Stepanova O, Polk M, Saldert H: Understanding mechanisms of conflict resolution beyond collaboration: an interdisciplinary typology of knowledge types and their integration in practice. Sustain Sci 2019 http://dx.doi.org/10.1007/s11625-019-00690-z.

46. Benham CF, Daniell KA: Putting transdisciplinary research into practice: a participatory approach to understanding change in coastal social-ecological systems. Ocean Coast Manag 2016, 128(August):29-39 http://dx.doi.org/10.1016/j. ocecoaman.2016.04.005.

47. Young JC, Waylen KA, Sarkki S, Albon S, Bainbridge I, Balian E, Davidson J, Edwards D, Fairley R, Margerison C et al.: Improving the science-policy dialogue to meet the challenges of biodiversity conservation: having conversations rather than talking at one-another. Biodivers Conserv 2014, 23(2):387-404 http://dx.doi.org/10.1007/s10531-013-0607-0.

48. Tinch R, Balian E, Carss D, de Blas DE, Geamana NA, Heink U, Keune H, Nesshöver C, Niemelä J, Sarkki S et al.: Science-policy interfaces for biodiversity: dynamic learning environments for successful impact. Biodivers Conserv 2018, 27(7):1679-1702 http://dx.doi.org/10.1007/s10531-016-1155-1.

49. Hessels LK, de Jong SPL, Brouwer S: Collaboration between heterogeneous practitioners in sustainability research: a comparative analysis of three transdisciplinary programmes. Sustain 2018, 10(12):4760 http://dx.doi.org/10.3390/su10124760.

50. Klenk N: From network to meshwork: becoming attuned to difference in transdisciplinary environmental research encounters. Environ Sci Policy 2018, 89(November):315-321 http://dx.doi.org/10.1016/j.envsci.2018.08.007.

51. Schmidt L, Hartberger K, Kobbe S, Falk T, Wesselow M, Schumann C: Stakeholder Involvement in Transdisciplinary Research: Lessons from Three Projects on Sustainable Land Management in a North-South Setting. GAIA; 2018 http://dx.doi. org/10.14512/gaia.27.3.12.

52. Ayala-Orozco B, Rosell JA, Merçon J, Bueno I, Alatorre-Frenk G, Langle-Flores A, Lobato A: Challenges and strategies in placebased multi-stakeholder collaboration for sustainability: learning from experiences in the Global South. Sustain 2018, 10:3217 http://dx.doi.org/10.3390/su10093217.

53. Blythe J, Nash K, Yates J, Cumming G: Feedbacks as a bridging concept for advancing transdisciplinary sustainability research. Curr Opin Environ Sustain 2017, 26-27(June):114-119 http://dx.doi.org/10.1016/j.cosust.2017.05.004.

54. Maassen S, Lieven O: Transdisciplinarity: a new mode of governing science? Sci Public Policy 2006, 33:399-410.

55. Turnhout E: The politics of environmental knowledge. Conserv Soc 2018, 16(3):363-371.

56. Mitchell C, Cordell D, Fam D: Beginning at the end: the outcome spaces framework to guide purposive transdisciplinary research. Futures 2015, 65(January):86-96 http://dx.doi.org/ 10.1016/j.futures.2014.10.007.

57. Montana J: Co-production in action: perceiving power in the organisational dimensions of a global biodiversity expert process. Sustain Sci 2019, 14(6):1581-1591 http://dx.doi.org/ 10.1007/s11625-019-00669-w.

58. Cvitanovic C, McDonald J, Hobday AJ: From science to action: principles for undertaking environmental research that enables knowledge exchange and evidence-based decisionmaking. J Environ Manage 2016, 183:864-874 http://dx.doi.org/ 10.1016/j.jenvman.2016.09.038.

59. Preller B, Affolderbach J, Schulz C, Fastenrath S, Braun B: Interactive knowledge generation in urban green building transitions. Prof Geogr 2017, 69:214-224 http://dx.doi.org/ 10.1080/00330124.2016.1208104.

60. Kirkegaard S, Andersen D: Co-production in community mental health services: blurred boundaries or a game of pretend?
Sociol Health IIIn 2018, 40(5):828-842 http://dx.doi.org/10.1111/ 1467-9566.12722.

61. Ott C, Kiteme B: Concepts and practices for the democratisation of knowledge generation in research partnerships for sustainable development. Evidence Policy 2016, 12:405-430.

62. Pereira L, Karpouzoglou T, Doshi S, Frantzeskaki N: Organising a safe space for navigating social-ecological transformations to sustainability. Int J Environ Res Public Health 2015, 12:6027-6044 http://dx.doi.org/10.3390/ijerph120606027.

63. Mansbridge J, Bohman J, Chambers S, Estlund D, Føllesdal A, Fung A, Lafont C, Manin B, Martí JL: The place of self-interest and the role of power in deliberative democracy. $J$ Polit Philos 2010, 18:64-100 http://dx.doi.org/10.1111/j.14679760.2009.00344.x.

64. Guinier L, Torres G: The Miner's Canary: Enlisting Race, Resisting Power, Transforming Democracy. Harvard University Press; 2003.

65. Jasanoff S: Technologies of humility: citizen participation in governing science. Minerva 2003, 41(3):223-244 http://dx.doi. org/10.1023/A:1025557512320.

66. Stirling A: Keep it complex. Nature 2010, 468:1029-1031.

67. Turnhout E, Tuinstra W, Halffman W: Environmental Expertise: Connecting Science, Policy and Society. Cambridge University Press; 2019.

68. Willis $\mathrm{P}$, Almack K, Hafford-Letchfield T, Simpson P, Billings B, Mall N: Turning the co-production corner: methodological reflections from an action research project to promote Igbt inclusion in care homes for older people. Int $J$ Environ Res Public Health 2018, 15:695 http://dx.doi.org/10.3390/ ijerph15040695.

69. Vanleene D, Voets J, Verschuere B: The co-production of a community: engaging citizens in derelict neighbourhoods. Voluntas 2018, 29(1):201-221 http://dx.doi.org/10.1007/s11266017-9903-8.

70. Mouffe: On the Political. Routledge; 2005.

71. Mouffe C: Agonistics: Thinking the World Politically. Verso; 2013.

72. Cuppen E: The value of social conflicts. Critiquing invited participation in energy projects. Energy Res Soc Sci 2018, 38:28-32 http://dx.doi.org/10.1016/j.erss.2018.01.016.

73. Metze T: Fuel to the fire: risk governance and framing of shale gas in the Netherlands. Extr Ind Soc 2018, 5:417-702 http://dx. doi.org/10.1016/j.exis.2018.09.016.

74. Maassen S: Collaborating in and beyond science. Obstacles and (somewhat surprising) opportunities. In Between/Beyond/ Hybrid. New Essays on Transdisciplinarity. Edited by Diaphanes Von Sass HnSs . 2019:101-124.

75. Klenk NL, Meehan K: Transdisciplinary sustainability research beyond engagement models: toward adventures in relevance. Environ Sci Policy 2017, 78(December):27-35 http://dx.doi.org/ 10.1016/j.envsci.2017.09.006.

76. Montana J: Accommodating consensus and diversity in environmental knowledge production: achieving closure through typologies in IPBES. Environ Sci Policy 2017, 68 (February):20-27 http://dx.doi.org/10.1016/j.envsci.2016.11.011.

77. Díaz-Reviriego I, Turnhout E, Beck S: Participation and inclusiveness in the Intergovernmental science-policy platform on biodiversity and ecosystem services. Nat Sustain 2019, 2:457-464 http://dx.doi.org/10.1038/s41893-019-0290-6.

78. Moore A: Critical Elitism. Cambridge and London: Harvard University Press; 2017.

79. Tsouvalis J, Waterton C: Building 'participation' upon critique: the Loweswater Care Project, Cumbria, UK. Environ Model Softw 2012, 36:111-121.

80. Waterton $\mathrm{C}$, Tsouvalis $\mathrm{J}$ : On the political nature of cyanobacteria: intra-active collective politics in Loweswater, the English Lake District. Environ Plan D Soc Space 2015, 33:477-493. 
81. Wyborn C: Connectivity conservation: boundary objects, science narratives and the co-production of science and practice. Environ Sci Policy 2015, 51(August):292-303 http://dx. doi.org/10.1016/j.envsci.2015.04.019.

82. Coates R, Garmany J: The ecology of citizenship: understanding vulnerability in urban Brazil. Int Dev Plan Rev 2017, 39:37-56 http://dx.doi.org/10.3828/idpr.2017.3.

83. Dunn G, Brown RR, Bos JJ, Bakker K: The role of science-policy interface in sustainable urban water transitions: lessons from Rotterdam. Environ Sci Policy 2017, 73(July):71-79 http://dx.doi org/10.1016/j.envsci.2017.04.013.

84. Polk M: Transdisciplinary co-production: designing and testing a transdisciplinary research framework for societal problem solving. Futures 2015, 65(January):110-122 http://dx. doi.org/10.1016/j.futures.2014.11.001.

85. Kowalczewska K, Turnhout E: The usability of scenario studies: the case of the eururalis from the users' perspective. Polish Sociol Rev 2012, 177:91-105.

86. Hajer MA: A media storm in the world risk society: enacting scientific authority in the IPCC controversy (2009-10). Crit Policy Stud 2012, 6:452-464 http://dx.doi.org/10.1080/ 19460171.2012 .730758$.

87. Kowalczewska K, Behagel J: How policymakers' demands for usable knowledge shape science-policy relations in environmental policy in Poland. Sci Public Policy 2018, 46:381390 http://dx.doi.org/10.1093/scipol/scy065.
88. Bua A, Escobar O: Participatory-deliberative processes and public policy agendas: lessons for policy and practice. Policy Des Pract 2018, 1:126-140 http://dx.doi.org/10.1080/ 25741292.2018.1469242.

89. McMillan R, Spronk S, Caswell C: Popular participation, equity, and co-production of water and sanitation services in Caracas, Venezuela. Water Int 2014, 39:201-215 http://dx.doi. org/10.1080/02508060.2014.886844.

90. Li TM: Governing rural Indonesia: convergence on the project system. Crit Policy Stud 2016, 10:79-94 http://dx.doi.org/ 10.1080/19460171.2015.1098553.

91. Turnhout E, Neves K, De Lijster E: "Measurementality" in biodiversity governance: Knowledge, transparency, and the intergovernmental science-policy platform on biodiversity and ecosystem services (ipbes). Environ Plan A 2014, 46:581-597.

92. Massarella K, Sallu SM, Ensor JE, Marchant R: REDD+, hype, hope and disappointment: the dynamics of expectations in conservation and development pilot projects. World Dev 2018, 109:375-385 http://dx.doi.org/10.1016/j.worlddev.2018.05.006.

93. Termeer CJAM, Metze TAP: More than peanuts: transformation towards a circular economy through a small-wins governance framework. J Clean Prod 2019, 240:118272.

94. Oliver K, Boaz A: Transforming evidence for policy and practice: creating space for new conversations. Palgrave Commun 2019, 5:60 http://dx.doi.org/10.1057/s41599-0190266-1. 